\title{
The changing geography and organisation of multinational agribusiness
}

\author{
Ruth Rama \\ IEGD-CSIC, \\ Albasanz, 26-28, \\ 28037 Madrid, Spain \\ Email: ruth.rama@cchs.csic.es
}

\begin{abstract}
We review several strands of literature, foreign direct investment (FDI) statistics and web pages of companies in order to understand current changes in the geography and organisation of multinational agribusiness. FDI in agriculture has soared, and multinational enterprises (MNEs) from emerging economies have become major international players, coinciding with the divestment from land of many Western-based MNEs. Much of land-related foreign investment in this sector consists of South-South investment. The liberalisation of land markets has been instrumental in facilitating the rapid expansion of foreign land deals. Paradoxically, corruption and anti-democratic practices have also favoured the swift expansion of foreign investment in agriculture. Agri-food MNEs based in the West have tended to divest from land and adopt new forms of international investment; this has helped them to stay in business in the face of adverse environments. Most agri-food MNEs from emerging economies have expanded, in contrast, through traditional FDI or foreign land leasing. However, several of these companies are implementing networked forms of production organisation, and this strategy is contributing to their rapid internationalisation. Academic and policy implications are discussed.
\end{abstract}

Keywords: multinational agribusiness; FDI in agriculture; liberalisation of land markets; MNEs from emerging economies; new forms of international investment; networked multinationals.

Reference to this paper should be made as follows: Rama, R. (2017) 'The changing geography and organisation of multinational agribusiness', Int. J. Multinational Corporation Strategy, Vol. 2, No. 1, pp.1-25.

Biographical notes: Ruth Rama is a Tenured Research Professor at the Institute of Economics, Geography and Demography of the Spanish National Research Council (CSIC). She has received her $\mathrm{PhD}$ degree from the Autonomous University of Barcelona. Her main research interests are in multinational enterprises and their interplay with national innovation systems; networks of innovators, and location of the R\&D activities of firms. She has published in international journals such as Environment and Planning A, Urban Studies, Technovation, Journal of Technology Transfer, International Journal of Technology Management, Science and Public Policy, European Planning Studies, and Industry and Innovation. 


\section{Introduction}

Agriculture is a crucial sector in many emerging economies since its growth could contribute to the growth of employment and to the reduction of poverty. According to UNCTAD (2009) data, in 2003 to 2007, the share of rural population in total population amounted to $57.3 \%$ in developing countries and to $36.0 \%$ in Commonwealth of Independent States (CIS) ${ }^{1}$ countries, versus only $24.7 \%$ in developed countries. The national impact of agriculture is still greater when attention is focused on full agribusiness chains, including food and drink processing, auxiliary industries and R\&D services to agriculture. In many developing and CIS countries, there used to be a bias against agriculture in favour of manufacturing; nevertheless, the agribusiness chain today is largely viewed as a potential engine of growth, export revenues, and modernisation of the economy (Hopewell, 2016; Katz, 2016; UNCTAD, 2009). However, the agriculture of many of these countries suffers from underinvestment. Multinational enterprises (MNEs) have become major players in models of development based on the exploitation of natural resources, and many policy makers and multilateral organisations believe that these corporations can help to solve this problem. In addition to increased land productivity, transfers of technology, and rural development, policy makers have often expected, in the poorest host countries, to obtain other benefits from FDI, such as improvements of the infrastructure and land irrigation (Adamczewski et al., 2013; Cotula et al., 2011). Therefore, the interest in better understanding new patterns of foreign investment in this sector is clearly justified.

The geographic patterns of foreign investment in agriculture are changing. The empirical evidence suggests that the prediction of Dunning (1993), namely that natural resources such as land would become less important for MNEs, may have been accurate for Western agri-food MNEs but not for agri-food MNEs from developing countries. This circumstance was certainly difficult to foresee at the beginning of the 1990s. Between 1990 and 2010, outward foreign direct investment (FDI) stock increased nearly six-fold in agriculture, and hunting, forestry and fishing (hereinafter, HFF) and its composition clearly changed. As noted by UNCTAD (2009), after a long period of minor FDI involvement in agriculture, a recovery may currently be underway, but coming from developing countries rather than from developed countries. The outward FDI stock from developing countries and CIS countries now stands at more than double that of developed countries. The share of foreign investors based in emerging economies is also substantial in foreign land deals other than FDI (e.g., land leasing) (Arezki et al., 2015; Borras et al., 2012; Gómez, 2014; Visser and Spoor, 2011). Organisation patterns are also changing in agri-food MNEs.

The purpose of this article is to shed more light on the evolution of agri-food MNEs. In doing so, we draw on several strands of literature, FDI statistics and web pages of companies to illustrate our arguments. In this specific research area, it is not always possible to rely exclusively on deductive reasoning and to put extant International Business (IB) theory to test. This restriction is due to the following reasons. As stated previously, the objects of analysis are relatively new and consist of unexpected IB phenomena. This is certainly a fast-moving global scenario. Most evidence on foreign land deals originates from the fields of Rural Sociology and Development Studies and not that of IB Studies. These studies are sensitive to real-life problems, especially to conflict between MNEs and other stakeholders in land deals, but rarely theorise specifically on the foreign investors engaged in such deals. Although literature on MNEs from emerging 
markets is appearing, very little theoretical knowledge exists about MNEs that operate, specifically, in agriculture and HFF. With some exceptions (in English, see for instance, Burch and Goss, 2005; Goss et al., 2000; Nazareth Satyanand, 2011), even empirical analyses in this topic are rare. The major proportion of work in the scholarly tradition of MNEs from emerging economies consists of cross-sectional studies, while guidance concerning specifically foreign investment in agriculture and HFF remains scarce. Consequently, part of the present article is of an exploratory character. Certain authors encourage the use of explorative analyses in IB studies since they opine that this method may contribute towards both the formulation of new research questions and the promotion of debate (Gligor et al., 2015).

What factors have contributed to the rapid expansion of land deals since the 1990s and why have agri-food MNEs from emerging economies been the main beneficiaries of such expansion? In order to answer these questions, a better understanding is required of how agri-food MNEs expand internationally. It is necessary to determine whether the international expansion of agri-food MNEs from emerging economies has been similar to the early expansion of agri-food MNEs from the West. In addition, explanations must be sought, and the relationship between international expansion and organisation in these companies must be analysed.

In doing so, this article attempts to fill a number of research gaps and points to topics that deserve more attention since IB theory has yet to provide a satisfactory explanation to the question. The literature on MNEs from emerging markets ${ }^{2}$ suggests that the expansion of these MNEs has been facilitated since firms currently operate in a 'flatter' world, due to, for instance, the liberalisation of international trade and of capital movements [Ramamurti, (2011), p.10]. However, this literature has yet to identify the pro-market reforms that could specifically have facilitated the international expansion of agriculture and HFF MNEs from emerging economies. Analyses from disciplines of the social sciences, which are rarely taken into consideration by the IB scholar, need to be consulted for this question to be fully understood. The recent rapid expansion of foreign land deals is also attributable to other location factors: notably corruption and antidemocratic institutions. According to IB theory, MNEs tend to avoid countries displaying these characteristics (see, for instance, Cuervo-Cazurra, 2006; Flores and Aguilera, 2007). In theory, these features are not viewed as a stimulus to the international expansion of MNEs. However, in the specific case of foreign land deals, the presence of both phenomena, corruption and anti-democratic practices, is well documented by context-rich studies in other strands of research work. Their apparent persistence is intriguing and, in our view, deserves to be explored. Finally, the statistical data mentioned above strongly suggests that most agri-food MNEs from the West have preferred not to profit from the new opportunities offered by the liberalisation of land markets; however, the motives of these companies remain unexplained. This article contributes towards filling these gaps in the literature, and attempts to build an explanation from the many pieces of information and analysis scattered across a multiplicity of sources.

Results of this research are as follows. Agri-food MNEs from emerging economies have internationalised in an especially supportive context due to the liberalisation of land markets. Corruption and anti-democratic practices have also favoured the swift expansion of foreign deals in agriculture. Often, the early international expansion of Western agri-food MNEs also involved conflict and corruption. However, when the liberalisation 
of land markets occurred, they had already been able to shift towards networked forms of organisation, which imply fewer risks. Even when opportunities for land acquisition became highly encouraging, these Western agri-food MNEs preferred to pursue this procurement strategy and renounced land ownership, leaving the field open to agri-food MNEs from emerging economies.

Section 2 reviews the literature and proposes our research questions. Section 3 starts by analysing conditions of international expansion faced by early agri-food MNEs from Western countries so that they may be later compared with the current conditions faced by agri-food MNEs from emerging economies. Most agri-food Western MNEs divested from agriculture and initiated a transition into networked forms of organisation, that is new forms of international investment (hereinafter, NFI, see definition below). Sections 4 and 5 explore the new external conditions in host countries, notably the liberalisation of land markets, which have facilitated the rapid international expansion of foreign land deals; and discuss the reasons behind the substantial presence of agri-food MNEs from emerging economies in the new scenario. Section 5 also focuses on the networked forms of organisation adopted by certain successful agri-food MNEs from emerging economies and on the implications of the analysis regarding the strategy of MNEs that operate in this sector. Section 6 provides conclusions and suggests future lines of research.

\section{Theoretical background and research questions}

The ownership-location-internalisation (OLI) paradigm of international production postulates that the stock of foreign assets owned or controlled by MNEs is determined by the specific ownership (O) advantages of firms, the location-bound (L) endowments offered by host countries, and the extent to which the market for ownership advantages are best internalised (I) by the company itself (Dunning, 1993). According to the OLI paradigm, policies of governments and the institutional framework constitute some of the specific L advantages offered by host-countries to potential foreign investors. The literature on MNEs from emerging markets suggests that the expansion of these MNEs has been facilitated because firms currently operate in a 'flatter' world, due to, for instance, the liberalisation of international trade and of capital movements [Ramamurti, (2011), p.10]. This literature argues that the rapid international expansion of these companies has been encouraged by pro-market reforms (Cuervo-Cazurra and Ramamurti, 2015).

Concerning other L advantages (or disadvantages), IB theory states that MNEs tend to avoid countries displaying characteristics such as corruption and anti-democratic institutions (see, for instance, Cuervo-Cazurra, 2006; Flores and Aguilera, 2007). However, the scholarly debate on the relationships of foreign investors and different political regimes remains inconclusive. The Dependency School postulates that MNEs benefit from dictatorial regimes, while the Neo-institutional School argues that MNEs would benefit more from a liberal democracy since this political regime provides stability for business (Bucheli, 2008). In the IB tradition, a quantitative analysis found that very large US MNEs are likely to invest in democratic countries (size and performance of the company; wages; population of the host country and other variables checked in the econometric model) (Flores and Aguilera, 2007). However, the sample used in the aforementioned study comprises 100 US companies pertaining to 27 different two-digit 
industries, and the authors do not claim that it is representative at industry level. We therefore conclude that more attention should be paid to the sector level.

Most studies found that corruption is a deterrent to FDI and Cuervo-Cazurra (2006) confirmed this point of view (gross domestic product, population of the host country, restrictions on FDI, and other variables were checked in his econometric model); however, he also found that the deterrence effect is not homogeneous on all foreign investors. Corruption, he established, is more likely to deter foreign investors based in countries that have signed the Organization for Economic Cooperation and Development (OECD) Convention on Combating Bribery of Foreign Public Officials in International Business Transactions. ${ }^{3}$ He concludes that corruption stimulates changes in the country composition of FDI since foreign investors exposed to bribery at home may seek countries where corruption is prevalent. Another study corroborates this point of view: in transition economies, MNEs coming from less corrupt countries are less likely to bribe officials in the host country and, consequently, these MNEs face a greater 'liability of foreignness' when corruption is pervasive (Oh, 2016).

Corruption and anti-democratic institutions in the host country often implies conflict between the foreign investor and local stakeholders. Certain areas of the world are 'ex ante' conflictive. Interestingly, an econometric study finds that conflict zones are more likely to attract foreign firms in mining and agriculture since these sectors, the argument goes, are bound by natural resources or geography (home country, number of subsidiaries, sales and other variables checked (Driffield et al., 2013). In other cases, however, conflict may be triggered by the behaviour of the foreign subsidiary.

This sort of climate, whatever its inception, could imply risk for the MNE, at least in the medium run. Unpopular governments may fall or receive pressure to comply with the requirements of local stakeholders. The capital market may deny finance to the company since its investments entail risk. Cantwell et al. (2010) maintain that MNEs have reacted to changes in the institutional environment in part by shifting towards network business structures that provide more flexibility. The theory of the networked MNE (see, for instance, Forsgren, 2013) focuses on the adoption of the networked form by MNEs that are already in place. This literature needs to be complemented with the empirical literature on MNEs from Japan and from certain peripheral European countries, which points to the existence of companies that had adopted networked forms of organisation at home, that is before internationalisation, and have later re-embedded these forms of organisation abroad (Rutherford, 2000; Rama and Ferguson, 2007).

Following the discussion, we propose four research questions:

RQ1 Which specific pro-market reforms, if any, have facilitated the current expansion of foreign land deals?

RQ2 Why have market reforms mainly encouraged the investment of agri-food MNEs from emerging economies?

RQ3 Have corruption and anti-democratic institutions played a role in the current expansion of foreign land deals?

RQ4 Facing conflict and risk, have agri-food MNEs been able to shift to networked forms of organisation? If so, under what specific premises? 


\section{Western-based investors}

Many early Western MNEs were unable to secure land. Others owned large plantations but finally had to divest, voluntarily or compulsorily, and these circumstances forced them into a substantial organisational adjustment (Subsection 3.1). Following the literature on new forms of international investment (Oman et al., 1989), we argue that changes in the institutional environment in developing countries that is nationalisation of plantations, and even the mere perspective of such changes, triggered organisational change in Western agri-food MNEs. Foreign companies that adopt NFI supply goods, tangible or intangible, to an investment project in a host country while local interests retain whole or majority ownership of the investment project or enterprise (Oman et al., 1989). Many NFI are networked forms of production organisation, such as contract farming. However, we claim that not all agri-food MNEs are able to adopt the networked form (Subsection 3.2).

\subsection{Access to land}

Historically, agri-food MNEs were among the first companies to internationalise their business (Stopford and Dunning, 1983). The early agri-food investor based in Europe or in the US often found that, in host countries, land was already in the hands of local élites, European immigrants, or expatriate investors. By the end of the 19th century, British investments in North-East Brazilian sugar mills were depicted as intrinsically more efficient than traditional, estate-based 'engenhos' controlled by the local oligarchy; however, British investors finally had to divest due to external difficulties in obtaining supplies of low-cost sugar cane since they had been unable to secure land (Abreu, 2000). In other Brazilian regions, other foreign investors divested before 1930 for the same reason: only vertically integrated processors were able to survive the sugar market crises of the end of the 19th century and the beginning or the 20th century (CEPAL, 1982). These foreign sugar subsidiaries, instead, had concentrated on processing and trade but owned no land. Early Western agri-food MNEs seem to have faced similar difficulties concerning land control in production and exports of beef in Argentina and Uruguay, and of coffee in Sāo Paulo (Brazil). Analysing changes in Latin American agriculture, Kay (2015, p.15) observes: "It could be argued ironically that land reform [of the 1960s to 1980s] facilitated in the end the process of land and capital concentration as it weakened the hold of the traditional landed class over land and thereby facilitated later with the neoliberal turn the development of an active land market".

Other institutions have also limited the operation of land markets. For instance, from 1917, a substantial part of Mexican land was controlled by 'ejidos' (collective landholdings) and indigenous communal tenure (Gordillo de Anda et al., 1998); the peasants were not allowed to sell or rent the land and this legal norm remained unchanged until the early 1990s. Even now, the long-standing Mexican tradition of agrarian reform has resulted in restrictions to the functioning of land markets (Gómez, 2014). For many early Western MNEs, investment in land was out of the question from the start, and consequently many concentrated on the processing and international distribution of food, rather than on land ownership (Suárez and Vigorito, 1981). These companies sourced local agricultural products mainly from local producers in arm's length markets. 
However, integration with agricultural activities and foreign trade was an important strategy for many other British and US agri-food MNEs in the early stages of their internationalisation (Stopford and Dunning, 1983). These firms controlled vast areas of land and exported goods such as tea, sugar, bananas, and beef to the USA and Europe (Herath and Weersink, 2009; Oman et al., 1989). Nevertheless, Western firms renounced controlling land owing to the nationalisation of their plantations, their own preference for other forms of procurement of agricultural products, or to their interest in more profitable businesses (Oman et al., 1989). During the period 1960 to 1976, agriculture stood in second place, after banking and insurance, among the businesses most affected by the nationalisation of foreign companies (UNCTAD, 2009). According to the aforementioned report, in many developing countries, the national control of land was viewed as a major factor of the decolonisation process. After the Second World War, foreign investment in agriculture and related industries declined considerably; many of the Western companies that divested from land subsequently focused on upstream or downstream industries rather than on agriculture (UNCTAD, 2009).

The following case studies illustrate the shift of early agri-food investors from the West, and lay out the reasons that induced them to divest from agriculture. Bucheli (2008) analyses the alliance between corrupt Central American Governments and a US banana MNE, the United Fruits Company. In 1900 to 1945, the less democratic a government was, the aforementioned author argues, the more inclined it was to accommodate the interest of the companies, usually against the interests of plantation workers, peasants and previous settlers. However, in the 1950s, two very large US banana producers operating plantations in Honduras started to sell their land as a response to violent and persistent conflict with local peasants, unionisation of plantation workers, and to expropriations of plantations in neighbouring Guatemala (Slutzky and Alonso, 1981). According to the aforementioned authors, by 1960, four large banana cooperatives had already purchased land once belonging to the banana MNEs. The foreign investors instead focused more and more on the international distribution of the product. The size of their plantations was reduced. They increasingly engaged in contract farming, providing credit, input, and technical advice to local contractual partners, often with the financial assistance of the local development bank or multilateral organisations. Another study (Herath and Weersink, 2009) reports that similar turmoil encouraged a shift in the tea sector of Sri Lanka, from vertically integrated plantations before the mid-1970s to a system in which independent processors of black tea purchased their inputs from local growers.

\subsection{Contract farming}

Conflict and political risk triggered organisational change in Western agri-food MNEs. The literature on NFI shows that, in the 1960s to 1970s, the majority of these companies adopted contract farming as a defensive reaction to the dangers of the nationalisation of plantations in developing countries (Oman et al., 1989). Moreover, financial questions also influenced their decision. For instance, United Fruits was viewed as a risk investment due to persistent conflict, and the company's risk ratios improved when it started to sell its Central American assets (Bucheli, 2008).

How did the adjustment to this changing environment occur in Western agri-food MNEs? In our view, these companies have been able to implement contract farming as a 
less risky and conflictive form of procurement due to their ownership (O) advantages. Several of these companies produce inputs used in farming, such as seeds and agri-chemicals, while others display a unique technological interface with providers of inputs since many of the agri-food companies are, in their own right, patentees of inventions in agriculture, chemistry, biotechnology, and drugs (Alfranca et al., 2004). In developing countries, linkages with auxiliary industries provide major agri-food MNEs with considerable monopsonic power in their relationships with local agricultural producers: in a specific producing region, they may be the sole buyers that are able to provide state-of-the-art agricultural inputs, often at cost price. Furthermore, a study of the world's 100 largest agri-food MNEs, most of which are Triad-based, reports that a number own independent subsidiaries, not attached to production centres, which specialise in technical services to farms (Filippaios et al., 2009). These subsidiaries often perform basic R\&D, and coordinate specialised agricultural and veterinarian research across countries in order to diffuse up-to-date technology generated in any of their centres of innovation across the entire multinational network. Secondly, the literature on contract farming suggests that these MNEs can have other O advantages, such as brand names that facilitate the international marketing of agricultural products (for instance, for fruits); this circumstance attracts skilled local contractual partners. Thirdly, in most developing countries, MNEs often have considerably more financial strength than rival domestic firms and this enables them to finance agricultural production (Oman et al., 1989). Finally, contractors need to enjoy substantial managerial capabilities in order to manage and centralise production from a network of contractual partners. Faced with most domestic rivals, these constitute formidable $\mathrm{O}$ advantages of Western agri-food MNEs in developing countries.

In 2010, approximately $30 \%$ of the outward FDI stock in agriculture and HFF came from developed countries (UNCTAD, 2009). However, most European and US food processors and retailers currently tend to outsource production to local suppliers of agricultural products rather than investing in land (Oman et al., 1989). Although their linkages with foreign agriculture are difficult to quantify, they have been well documented by case studies (see, for instance, Aznar-Sánchez, 2006; Echánove and Steffen, 2005; Gwynne, 2006; UNCTAD, 2009). These companies produce a variety of products under contract, including fruits, milk, and poultry. Oman et al. (1989) describe such arrangements as NFI (not simply FDI). MNEs that outsource agricultural production often also finance, organise production, and influence the technological practices of their local suppliers, even though they own no land, and thereby growers retain land ownership.

The contract farming practices of agri-food MNEs from developed countries have sometimes posed problems with local farmers since these arrangements often give the buyer considerable power on price and quality of agricultural products. In contrast to the plantation system, much of the risk of agricultural production is shouldered by the growers (Oman et al., 1989). It has also been claimed that these schemes tended to exclude small farms because the companies often preferred to outsource products from medium-sized to large farms that were better equipped with technology and water, and whose farmers were better skilled. However, the literature suggests that levels of conflict and uncertainty are lower than those prevailing in the initial phase of expansion of Western agri-food MNEs. 


\section{The changing scene of foreign land investment}

\subsection{A rush towards land}

The panorama of foreign investment in agriculture and related industries changed with the neoliberal turn. As stated in the introduction, between 1990 and 2010, FDI stock increased nearly six-fold in agriculture and HFF (Table 1). In 2007 to 2008, the global food crisis encouraged a rush toward land due to the rise in food prices, to fears concerning food security in countries that were not self-sufficient, and to a reaction to insecurity in other sectors at the inception of the crisis (Arezki et al., 2015; Visser and Spoor, 2011). According to certain authors, nevertheless, a slowdown of agricultural FDI may have taken place after 2008, at least in two target regions: Africa and post-Soviet Eurasia (Arezki et al., 2015; Cotula et al., 2014; Visser and Spoor, 2011). However, a number of agri-food MNEs from developing countries have done well even during the crisis: Banco do Brasil reports that the outward Brazilian FDI stock in agriculture, fishing and mining nearly doubled in 2007 to 2013 alone. ${ }^{4}$

FDI statistics only include data on foreign land deals that involve land acquisitions. However, today's foreign land deals comprise other formulae, such as foreign land leasing. Therefore, this statistical data needs to be complemented with information captured by studies on foreign land deals other than those involving FDI. Unlike FDI, these formulae imply no changes in land ownership, and are not registered by the sources cited above, that is, by UNCTAD statistics or by FDI reports of central banks. Other sources of information need to be consulted to provide a vision of the full panorama of foreign land deals in this sector. We return to this question below.

Table 1 Estimated outward FDI stock worldwide in agriculture and related industries (hunting, fisheries and forests) 1990 and 2010 (millions of dollars and percentages)

\begin{tabular}{lcllcccc}
\hline \multicolumn{3}{c}{1990} & & & \multicolumn{4}{c}{2010} \\
\cline { 1 - 1 } \cline { 5 - 6 } $\begin{array}{l}\text { Developed } \\
\text { countries }\end{array}$ & $\begin{array}{c}\text { Developing } \\
\text { countries }\end{array}$ & World & & $\begin{array}{c}\text { Developed } \\
\text { countries }\end{array}$ & $\begin{array}{c}\text { Developing } \\
\text { countries }\end{array}$ & $\begin{array}{c}\text { South East } \\
\text { Europe and CIS }\end{array}$ & World \\
\hline 4,012 & 360 & 4,372 & & 7,294 & 16,653 & 101 & 24,049 \\
$(91.8 \%)$ & $(8.2 \%)$ & & & $(30.3 \%)$ & $(69.2 \%)$ & $(0.4 \%)$ & \\
\hline
\end{tabular}

Note: ${ }^{1}$ Commonwealth of Independent States.

Source: UNCTAD

\subsection{Origin of capital}

Table 1 shows the evolution of outward agriculture FDI stock in 1990 to 2010 for both developed and developing countries. The composition of outward FDI changed substantially and the share of developed countries fell during this period. The reduction was substantial (from $92 \%$ of total FDI to only $30 \%$ ) owing to the dynamic expansion of FDI originating in emerging economies. In agriculture and HFF, the outward FDI stock from these economies now stands at more than double that of developed countries. As shown by Table 1, the share of CIS countries (and South-East Europe) is very small. However, as shown below, the presence of these investors is significant at regional level, especially when land deals other than FDI are considered. Within the group of emerging economies, Malaysia, Thailand, Sri Lanka, Indonesia, and South Africa stand out as the 
homes of several of the world's largest agriculture-based and plantation MNEs (UNCTAD, 2009).

Much of the outward FDI of emerging economies in agriculture and HFF consist of FDI channelled to other emerging economies. These countries are the main receivers of FDI ( $69 \%$ of total inward FDI stock worldwide of agriculture and HFF). Within this group, the main receivers are China, followed at a distance by the Russian Federation, Chile, and Ukraine (UNCTAD, 2009). Certain developed countries have increased controls over foreign land deals; this is the case of Canada, Australia and several US states, which are all agriculturally rich areas (Magnan, 2015; Nickerson et al., 2012). Although these countries are also substantial receivers of FDI in agriculture and HFF, the new policies may have limited the location choices of foreign investors during the last period; in addition to high prices of land in such countries. Unfortunately, the data available is insufficient to enable a detailed analysis of the geography of investment flows.

As stated, other formulae of foreign land deals also need to be taken into account. Data for estimated agricultural FDI may undervalue the importance of land-related foreign investment due to the sole inclusion by this data of purchases of land and to the exclusion of other formulae of foreign land deals, such as leasing. The problem is that land purchases are not necessarily the norm. The geography of FDI and the geography of other foreign land deals seem to differ, one reason being the characteristics of land tenure in different countries. In certain countries, farmers are not allowed to sell land and, therefore, formulae of foreign land deals other than FDI may be common since these formulae do not involve acquisitions. Land purchases represent the common formula of foreign land deals in the USA, Western Europe, Australia and Latin America and, to a lesser extent, in Eastern and Central Europe and the Middle East and Northern Africa (Arezki et al., 2015). Therefore, agricultural FDI is easier to trace in these areas. However, other formulae that are more difficult to trace are widespread in other regions of the world (Brondeau, 2010; Cotula et al., 2014; Visser and Spoor, 2011). African Governments prefer 18-year to 99-year leasing and, consequently, land is not formally sold to the foreign investor (Brondeau, 2010). Ever since the colonial phase, irrigated land in West Africa has been in the hands of governments, and not of farmers (Adamczewski et al., 2013). In certain regions of Tanzania, land is acquired through sub-leases of estates run by parastatals, while in Ghana, part of the land belongs to customary chiefdoms and extended families (Cotula et al., 2014). Consequently, in Sub-Saharan Africa, purchases account for only $28 \%$ to $33 \%$ of total land projects (Arezki et al., 2015). Scholars agree that information on foreign land deals other than FDI is scarce and insufficiently transparent (Arezki et al., 2015; Brondeau, 2010; Cotula et al., 2014; Gómez, 2014). The information available on these foreign land deals originates from: surveys; the journalistic and business literature; cadastral national records; and non-government organisations (NGOs), such as GRAIN or the International Land Coalition (for details on these sources of information, see, for instance, Arezki et al., 2015).

According to three different databases, in Sub-Saharan Africa, investors from East Asia and the Middle East accounted for $18 \%$ to $43 \%$ of the total number of land projects; and African investors accounted for $15 \%$ to $27 \%$ (Arezki et al., 2015). Western investors amounted to $43 \%$ to $57 \%$. In Latin America and the Caribbean, the protagonists of most land deals are intra-regional MNEs, sometimes allied with extra-regional investors and host governments (Borras et al., 2012; Gómez, 2014). In the European 
Black Earth area of Russia and Ukraine, land deals are dominated by Western investors, with Middle Eastern investors recently entering the market (Visser and Spoor, 2011). In Siberia, these authors claim, Asian investors (e.g., China, South Korea, and Japan) are the most active and, in Kazakhstan and Russia, there are intra-regional investors. Following the Uppsala school of thought (Johanson and Vahlne, 1977), the substantial presence of intra-regional investors is attributable to the small 'psychic distance' between the home country of the foreign investor and the host-country. Common language, similar culture and probably similar agricultural conditions have facilitated the penetration of MNEs in neighbouring markets for land. The evidence suggests that the presence of investors from developing countries is significant in all geographic areas. Investors from CIS countries mainly focus on intra-regional investment, since Russia, Ukraine and Kazakhstan are among the countries with the largest untapped agricultural resources in the world (Visser and Spoor, 2011). According to this literature, China and the Middle East seem to be the main investor countries, while African countries seem to be the main recipient countries. However, as observed in the aforementioned reported case of FDI, the available data fails to enable a detailed analysis of the geography of these foreign land deals.

\subsection{Demand-side considerations}

Demand-side considerations contribute towards explaining why agri-food investors from emerging economies constitute the most important protagonists in the current scenario. The stagnation of the aggregated domestic demand due to aging of the population and low elasticity of the demand has encouraged the world expansion of Western agri-food MNEs. Demand-side issues are also playing some role in the internationalisation of agri-food companies from emerging economies. Certain authors argue that the main objective of South-South agricultural investment is to obtain cheap food for the home market, thereby bypassing large multinational trading companies based in the North (McMichael, 2012). An econometric study suggests that food self-sufficiency of the home country contributes towards explaining whether companies are likely to embark on foreign land deals: per capita food imports in origin countries were strongly positively associated with higher demand for land investment in Africa (Arezki et al., 2015).

Other countries, such as Brazil, are self-sufficient in food production but their food consumption patterns are changing. These countries are undergoing major socio-economic changes, such as rapid urbanisation processes, a substantial increase of households leaving poverty behind, and the rapid growth of the middle-classes. These developments have contributed towards increases in food consumption and, at the same time, a shift from traditional consumption patterns based on cereals towards a diet that also includes beef, fish, vegetables, fruits and fats. The diversification of the internal demand has constituted a good business opportunity for large domestic firms and a stimulus for their internationalisation. The world expansion of Brazilian MNEs operating in the meat, poultry, and pork businesses went hand in hand with rapid increases in the domestic demand for these products, a rise of quality and safety standards along the food-chain, technological upgrading of the companies, concentration of domestic capital through mergers and acquisitions (M\&A), and previous divestment of foreign MNEs (Müller, 1980; Stal et al., 2010). As predicted by the IB literature (Cuervo-Cazurra and Ramamurti, 2015; Luo and Tung, 2007), certain limitations faced by the company in the home country have also stimulated internationalisation of certain agri-food MNEs from 
emerging economies. For instance, the Brazilian beef producers (e.g., JBS, Marfrig, Sadia, Perdigão) that internationalised in countries such as Argentina, Uruguay and Australia, have sought to extend the export quotas imposed on Brazil by the European Union (EU) and, most importantly, to export beef to the Northern Hemisphere from countries with a better sanitary reputation than the home country (Stal et al., 2010). One reason for the international expansion of Indian oilseed MNEs has been corporate landownership restrictions in the home country (Nazareth Satyanand, 2011). Certain agri-food MNEs from emerging economies control various segments of the food value chain (Bell and Scott, 2010; Nazareth Satyanand, 2011; Pozzobon, 2008). They may have land under production in other emerging economies, and processing and retailing facilities in developed countries or in the home country.

The question of food self-sufficiency leads us to a brief digression on the role played by home governments in the international expansion of agri-food companies from emerging economies. We turn to this question below.

\subsection{The role of governments}

Behind the presence, in land deals, of certain governments of developing countries that are not self-sufficient, is the search for cheap food for the home country. Visser and Spoor (2011) found that one feature that distinguishes, in post-Soviet Eurasia, land investments by Asian companies and land investments by Western companies is that Asian investments are often made by governments, by provincial-level authorities, or by private investors guaranteed by governments. In African land deals, the presence of public-sector foreign investors from developing countries is substantial in the form of sovereign funds, cooperation institutions, and so on (Chaponnière et al., 2011). According to certain authors, such deals often go beyond the agri-food sector and involve geopolitical issues (Brondeau, 2010).

However, government intervention is not necessarily motivated by concerns on food self-sufficiency. Brazil successfully moved into the production of temperate agricultural products thanks to the 'construction' of comparative advantages promoted by the active intervention of the state backed by lobbies of domestic agribusiness (Hopewell, 2016). Furthermore, the Brazilian Government purposefully supported the internationalisation of domestic agri-food firms; for instance, by promoting the merger of two large domestic firms active in the international meat processing sector, Sadia and Perdigão. ${ }^{5}$ The merger enabled these companies to acquire international scale. Brazilian Banco Nacional de Desenvolvimento (BNDES), the largest development bank in the world, financed the globalisation of two other large domestic agri-food firms, JBS-Friboi and Brasil Foods (Casanova, 2010). In attempting to consolidate domestic companies that are globally competitive, BNDS has also financed investment in ranching areas of Northern Brazil (Wilkinson et al., 2012). These developments seem to confirm the point of view of Sim (2007), who claims that the so-called 'Western theories' regarding MNEs have neglected the role played by government support, which, in some emerging economies, made a major contribution to the success of companies based in those countries. Indeed, governments of developed countries have been rarely involved in the overseas projects of agri-food MNEs during the period analysed here ${ }^{6}$, an important exception being the Japanese Government (Dunning, 1993; Rama and Wilkinson, 2012). 


\section{A new framework for international expansion}

This section analyses certain crucial external conditions that have recently facilitated the international expansion of agri-food MNEs.

\subsection{Reform of land markets}

According to researchers working in the field of MNEs from emerging economies, one relevant consideration necessary for the understanding of the success of these MNEs is that they internationalise their businesses in a world which today is 'flatter' in terms of international trade, freedom of capital movements, and so on (Ramamurti, 2011).

The dynamic growth of current agricultural FDI cannot be fully understood without taking into account the liberalisation of land markets and the conversion of collective and customary land rights into formal, individual rights: a policy followed by most developing countries and CIS countries in the 1990s (Zoomers, 2010). This is the pro-market reform that has specifically facilitated foreign land deals. Other aspects of the neoliberal turn have also played a role: in many of these countries, neoliberal policies simultaneously encouraged the dismantling of public agencies that had formerly provided credit, technical assistance and insurance to small farmers. This circumstance encouraged many farmers to sell their land to foreign investors. A positive attitude of the local government towards FDI certainly provides a powerful attractor to a host country (Dunning, 1993). This view is strongly supported concerning, specifically, the current phase of foreign investment in agriculture and HFF. In the end of the 1980s, Oman et al. (1989) asked whether the trend towards NFI in developing countries would be reversed, and concluded that governments were already attempting to attract new flows of traditional FDI; many developing countries needed finance and considered that, in this respect, traditional FDI was more advantageous than NFI. Mexico and India have been reluctant to allow FDI in agriculture and HFF (Gordillo de Anda et al., 1998; Nazareth Satyanand, 2011). However, most host governments of emerging economies have been instrumental in facilitating such investment, especially when the targeted land had been defined as available marginal land or was located in agricultural frontier regions (Borras et al., 2012; Brondeau, 2010; Visser and Spoor, 2011). Brondeau (2010) interprets the growth of land-related foreign investment in Africa as the result of unsuccessful agricultural development policies and the parti-pris of local governments in favour of large agribusinesses, rather than family farms. We conclude that the liberalisation of land markets has been instrumental in facilitating the rapid expansion of foreign land deals. It was in this new business atmosphere that agri-food MNEs from emerging economies have internationalised.

Why have major Western agri-food MNEs renounced the opportunity to take advantage, to the same extent as MNEs from emerging economies, of the new favourable institutional and policy framework for land deals? Although Western MNEs had been initially encouraged to divest from agriculture and adopt contract farming, over time the majority of these firms considered that this arrangement was clearly the best option since it reduced political and economic risk, increased flexibility, and enabled them, in certain cases, to adopt an itinerant location strategy and move to newly opened agricultural areas within the host country (Frédéricq, 1981; Oman et al., 1989). Other reasons can be mentioned: analysing a sample of very large Triad-based agri-food MNEs, an 
econometric study found that vertical integration with agriculture is not a characteristic associated with rapid international growth. In contrast, the ownership of specialised, knowledge creating subsidiaries is associated to rapid growth (size and other variables are checked) (Rama, 1998). As stated in Subsection 3.2, the presence of such subsidiaries often denotes the engagement of the MNE in contract farming. It is off course difficult to generalise from anecdotal evidence but it would seem likely that changes in organisation have involved changes in the geographic strategy of the agri-food MNE. For instance, Tate \& Lille, a British MNEs once well-known for its sugar plantations in The Caribbean and other tropical areas, has currently a home region strategy due to divestment from agriculture and subsequent focus on other segments of the food chain (Oman et al., 1989; Filippaios and Rama, 2008).

\subsection{Corruption and anti-democratic institutions}

We argue here that, paradoxically, anti-democratic institutions and corruption in host countries have also contributed towards the growth of foreign land deals. As stated in Section 2, IB theory has paid insufficient attention to the particularities of sectors. As shown below, the panorama concerning the recent location choices of foreign land investors in terms of political regimes greatly differs to that depicted by Flores and Aguilera (2007). On analysing deals taking place in Africa, Arezki et al. (2015) found that the less protected the rights of peasants, the higher the investor interest in land-related investment. This result was confirmed no matter which database was used in their econometric analyses (former colonial relationships, population, yields, and other variables were also checked). The finding of Arezki et al. (2015) is corroborated by the analysis of a panel comprised of 156 countries that were studied during 2000 to 2011: Bujko et al. (2015) found that democratic institutions make large-scale land deals less likely (availability of arable land, population density, and other relevant variables are checked in the econometric model). They argue that governments subject to democratic controls are less likely to agree to large land deals since they need to cater to local demands.

In this respect, the case of Chile is interesting since it shows the medium-term effects, on FDI in agriculture and HFF, of the conjunction of the liberalisation of land markets, on the one hand, and an authoritarian regime, on the other. Chile was a precursor concerning the liberalisation of land markets. Neoliberal reform was particularly effective there for two main reasons. Firstly, Chilean economists, trained at the University of Chicago, were promoted to positions of power since the mid-1970s, during the rule of General Pinochet ${ }^{7}$ (Valdés, 1995). The Department of Economics at the University of Chicago advocated a climate of deregulation. The second reason why neoliberal reform was particularly effective in Chile was that those who opposed it were silenced: General Pinochet's regime was an authoritarian regime. According to certain authors, the military's government privatisation of national assets such as forests, and the partial rollback of land reform, amounted to the reprivatisation of formerly public goods; from 1973, massive expulsions of peasants took place (Arce and Marsden, 1993). In the medium run, the concurrence of neoliberal reform and an authoritarian regime clearly facilitated foreign land investment: Chile is currently one of the main host countries for FDI in agriculture and HFF, although its availability of arable land is limited (UNCTAD, 2009). In our view, the concurrence of both factors, authoritarian regimes and the neoliberal turn, has been crucial: over a similar period of time, the Brazilian authoritarian 
regimes increased control over foreign land deals (Wilkinson et al., 2012) since their point of view was nationalistic rather than neoliberal.

The evidence available on foreign land deals does not support the widespread thesis concerning the location choices of MNEs, namely that these companies are deterred by anti-democratic institutions and by corruption (see, for instance, Cuervo-Cazurra, 2006; Flores and Aguilera, 2007). According to an econometric study, large-scale land deals are more likely to take place in corrupt countries (Bujko et al., 2015). The aforementioned authors calculated that "a one-unit increase in corruption control is associated with a 64 percent reduction of the expected odds of observing a land deal" (p.9). Their study does not establish whether corruption is a deterrent in the case of certain nationalities, since the model does not control for the origin of capital.

Several possible explanations for this counter-intuitive conclusion can be explored here, although in a preliminary manner only. It might be thought that the location choices of foreign investors operating in natural resources are more limited than those of foreign investors operating in other sectors. The agricultural potential of various countries is not homogeneous and depends on a variety of factors, such as the quality of soil. MNEs that operate in agriculture and HFF would be less mobile than other MNEs and, therefore, would be ready to cope with any political regime or business climate, on the condition that the host country enjoyed natural resources. However, this hypothesis is not supported by research results. On studying Africa, Arezki et al. (2015) found that the agri-ecological potential is certainly a pull factor for large-scale agricultural investment; however, the business climate in the host country is insignificant in their econometric model and weak tenure security is associated with increased interest of investors to acquire land there. Bujko et al. (2015), who found that large land deals tend to occur in corrupt countries, controlled for the availability of arable land and for cereal yields in their econometric model. Following the line of reasoning of Cuervo-Cazurra (2006) and Oh (2016), another explanation may be associated to the origin of foreign capital invested in agriculture and HFF: MNEs from certain emerging economies may be willing to invest in corrupt host countries because they are used to dealing with corruption in their home countries. Further theoretical and empirical research is clearly needed to assess the relevance of these explanations. We conclude that anti-democratic institutions and corruption have also favoured the rapid expansion of foreign land deals.

\subsection{Conflict}

Not surprisingly, conflict concerning current foreign land deals, although not widespread, is apparent in many geographic areas, and has started to provoke instability and uncertainty of investments. In the two Ukrainian regions analysed by Mamonova (2015), and in most Latin American countries (Gómez, 2014), land deals involving foreign investors have seldom been contested. In Ukraine, peasants have perceived the new latifundia as a continuation of large Soviet collective property; they have not been dispossessed of their own family plots, and they have been somewhat 'included' in the profits made by the new investors (Mamonova, 2015). In Latin America, despite the dispossession of the very poor, many other growers have become mini 'rentiers', by renting their land to foreign investors (Gómez, 2014). However, in other geographic areas, land deals have often involved criticism by public opinion and serious confrontation with local rural populations. There are growing international concerns 
about the recent surge in large-scale vertical investments in developing-country agriculture by foreign investors (Mirza et al., 2015). Most authors admit that it is often difficult to distinguish between the so-called 'land grabs' and agricultural foreign investment (Cotula et al., 2009). ${ }^{8}$ Adamczewski et al. (2013), analysing irrigated areas of Mali, report that most investors failed to respect the terms agreed with the host government; for instance, their engagement to build infrastructure and to promote land irrigation. Another study reports on the continued protests of peasant organisations in Western Africa (Brondeau, 2010). High levels of conflict and malpractice around deals have also been detected in certain regions of post-Soviet Eurasia (Visser and Spoor, 2011). In certain countries, the complexity of land tenure, the weight of legally contested areas, and the difficulty of formulae employed in foreign land investment (Subsection 3.2) contributes towards explaining conflict.

These circumstances have affected the development of investment projects in certain cases. In Western Africa, certain projects have been delayed due to conflict of foreign companies with local peasants or because investors broke the leasing conditions to which they had subscribed with the host government (Adamczewski et al., 2013; Brondeau, 2010). On analysing agricultural-related investment in Mali, a study suggests that many foreign investors may withdraw, in the medium-term, due to high levels of risk (Adamczewski et al., 2013). This is not the only case in which socially detrimental practices may lead to the exit of the initial agricultural investor (Mirza et al., 2015). The situation currently being faced by certain investors from emerging economies is similar to the situation faced by early Western investors who owned plantations (Section 3).

Are the circumstances mentioned above encouraging those investors from emerging economies to shift towards NFI, which involve less conflict and risk?

\subsection{Adopting new forms of investment}

As shown in Section 3, most Western agri-food MNEs divested from agriculture but, nevertheless, were able to stay in business in challenging environments. They adopted new forms of international investment that is contract farming, as a reaction to conflict and institutional change in the host country. In contrast, most agri-food investors from emerging economies have expanded worldwide through land ownership and other formulae of foreign land deals, such as land leasing. However, there are exceptions.

This subsection focuses on one of such exceptions, that is on certain South American agri-food MNEs that have adopted networked forms of organisation called 'sowing pools'. ${ }^{9}$ At the global level, these companies still account for a relatively small share of foreign land deals. However, it is interesting to study them because the case of these companies contributes to understanding why certain agri-food MNEs from emerging economies may be able to adopt NFI. It should be stressed that, in these companies, organisational change has not been necessarily triggered by conflict. We claim that they differ from Western agri-food MNEs in that they adopted the networked form before internationalisation, and this circumstance, in turn, has facilitated their regional expansion. As indicated in Section 2, the empirical literature has analysed this strategy in other latecomer international investors whatever their sector; it has been claimed that cultural factors could account for the predisposition of firms to cooperate. In the two largest South American producer countries. Argentina and Brazil, the success of agribusiness depends on a model characterised by: non-tilling, high-tech agriculture and large-scale production (Craviotti, 2016; Hopewell, 2016). Certain authors believed that 
the replication of this model in other developing countries would imply eviction of peasants and social upheaval since 'extreme land concentration' is essential to this model [Hopewell, (2016), p.14]. Certain Argentinean MNEs are actually replicating this agri-food model in several other South American countries (Bell and Scott, 2010; Gómez, 2014, Craviotti, 2016), but the anticipated negative social effects are not taking place. One possible reason is the organisation of the MNE into 'sowing pools': access to land is provided by a multiplicity of small and medium-sized estates through contracts or land provided in trust, and this enables the MNE to control large extensions of land (Gómez, 2014). If these relatively small plots had not been combined with others, the aforementioned author argues, they would not have been viable for growing crops that require economies of scale (such as cereals and oilseeds). A large number of farmers, he claims, have avoided dispossession thanks to these arrangements since, in 'sowing pools', farmers retain land ownership. However, other studies observe that the benefits obtained by local partners depend on their respective access to resources and to their position within the network (Craviotti, 2016; Bell and Scott, 2010).

Previous to internationalisation, these MNEs had a long-lasting experience with agriculture and, specifically, with managing 'sowing-pools' in the home country (Bell and Scott, 2010; Craviotti, 2016; Gómez, 2014). 'Sowing pools' emerged, in Argentina, by the mid-1990s and rapidly expanded there in the 2000. In this case, the avoidance of conflict was not the main objective of the agri-food companies. ${ }^{10}$ In Argentina, there was already a long tradition of contract farming, and strong property-rights protection had been granted since the second half of the 19th century (Bell and Scott, 2010); these circumstances may have limited the potential for conflict around land deals. The agri-food companies instead looked for increased flexibility (Craviotti, 2016; Bell and Scott, 2010). The networking and managerial skills acquired over time in the home country are now instrumental in facilitating the regional expansion of these Argentinean MNEs. However, their level of embeddedness in the home country and in various host countries differs (Craviotti, 2016), and this is in accordance with theories of the networked multinational. On the other hand, within the same host region, the Argentinean 'sowing pools' may co-exist with other models of foreign land investment: in the Brazilian 'Cerrados' region, they co-exist with a flow of US farmers and with Chongqing Grain Corporation, a Chinese state-owned company (Wilkinson et al., 2012).

As stated in Section 3, involvement in NFI requires the possession of certain $\mathrm{O}$ advantages on the part of the agri-food MNE. The Argentinean agri-food MNEs involved in 'sowing pools' are no exception to this rule. This is a major reason why this case is particularly interesting since certain authors claimed that MNEs from emerging economies have no $\mathrm{O}$ advantages (Rugman and Nguyen, 2015). However, in our view, a distinction concerning different types of $\mathrm{O}$ advantages needs to be made here: $\mathrm{O}$ advantages may derive from particular, unique assets of the firm, such as patents; secondly, firms may also have $\mathrm{O}$ advantages of a collective type that include the overall organisational abilities of the firm, the experience and capabilities of its managers, its political contacts, and its long-term business agreements with other firms (Cantwell, 2000). The capacity to orchestrate internal and external resources effectively can be considered an organisational capability of the enterprise, which could be first developed for the domestic market and only later become a source of $\mathrm{O}$ advantages abroad. The above mentioned Argentinean MNEs combine their own resources and a variety of external resources. Finance is provided by investment funds. The MNE contacts various 
external specialised teams to sow, fumigate, harvest, and transport the product; after the harvest, the profits are distributed among the teams and the landowners. The commercialisation of the product is guaranteed by the association of the MNE with one or several international value-chains. According to Gómez (2014), the capacity to manage, coordinate and negotiate is a distinctive feature of the MNEs involved in 'sowing-pools', much more so than their own technological capabilities. A leading Argentinean agri-food MNE defines itself as "the coordinator of its network of suppliers, with high quality standards behind a shared vision" [Bell and Scott, (2010), p.4]. These companies may not have unique $\mathrm{O}$ advantages but they clearly possess $\mathrm{O}$ collective advantages.

This phenomenon is difficult to measure since 'sowing pools' are not reported in official land statistics (Craviotti, 2016). Nevertheless, the small amount of data available on 'sowing pools' can be very telling. Los Grobo group, a leading Argentinean MNE, has 250,000 hectares of land under production in South America, of which 90,000 hectares in the home country (Bell and Scott, 2010), and is planning now to implement its model in Portuguese speaking Africa and China. ${ }^{11}$ One study calculates that, in Brazil alone, agri-food Argentinean MNEs have 700,000 hectares of land under production. ${ }^{12}$

The discussion suggests that agri-food MNEs from emerging economies can adopt NFI. However, in areas of the world other than South America these cases remain exceptions, probably since most of these corporations lack the $\mathrm{O}$ advantages required to embark on NFI. This remains an open question, with the obvious need for further and better data.

\subsection{Implications for the strategy of MNEs}

As business history clearly shows us, any international expansion that goes hand in hand with persistent conflict in the host country presents a major risk. Western agri-food MNEs and agri-food MNEs from emerging economies tend to use two different strategies of procurement: the strategy of the latter MNEs imply land ownership while that of the former MNEs do not imply land ownership. The networked form of procurement adopted by most agri-food MNEs from the West (and a few agri-food MNEs from emerging economies) may leave part of the profits of agribusiness in the hands of local partners. In consequence, this procurement involves fewer conflicts with local stakeholders and, hence, fewer risks for the MNE. However, the successful implementation of this form of organisation requires the development of the foreign investor's $\mathrm{O}$ advantages, in terms of both new technology and efficient management at the subsidiary level.

\section{Conclusions}

After a long period of stagnation, FDI in agriculture has soared, and its composition has clearly changed: the outward FDI stock from developing countries and countries of the CIS now stands at more than double the investment of developed countries. The presence of the new investors is also substantial in foreign land deals other than FDI. Much of land-related foreign investment in this sector seems to consist of South-South investment.

The research work supports theories concerning MNEs from emerging markets (e.g., Cuervo-Cazurra and Ramamurti, 2015): making the world 'flatter', pro-market reforms have clearly favoured the expansion of MNEs from emerging economies. It shows that 
this 'flatness', in the specific case of agri-food MNEs, is due to the relatively recent liberalisation of land markets. In contrast, we find no evidence to support the idea that corruption and anti-democratic institutions in the host country constitute deterrents to foreign investment (Cuervo-Cazurra, 2006; Flores and Aguilera, 2007), and the review of the literature implies rejection in the specific case of foreign land deals. This conclusion runs sharply against the results of previous IB studies, and lays bare the issue of the specificity of foreign land deals. On the other hand, research work confirms that, when the institutional environment changes, agri-food MNEs tend to evolve towards networked forms of organisation, as suggested by Cantwell et al. (2010), and that these forms, in agriculture, are NFI in which local partners maintain land ownership (Oman et al., 1989). Often, the early international expansion of agri-food MNEs from the West also involved conflict and corruption but, when the neoliberal turn occurred, they had already been able to shift towards networked forms of organisation that imply fewer risks. Even when international conditions for land acquisition became highly favourable, most preferred to preserve this strategy and renounced land ownership, leaving the field open to agri-food MNEs from developing countries. However, the possession of ownership advantages on the part of the MNEs constitute the foundation of networked forms of organisation and this pre-condition is not met by all foreign investors.

Our research has several policy implications. In host countries, NFI seem to involve lower levels of conflict than traditional FDI and other formulae of foreign land investment. The main difficulty lies in the fact that most of the agri-food MNEs from emerging economies seem currently unable to adopt formulae that imply lower levels of conflict, such as NFI, due to their insufficient ownership advantages. A major difference between MNEs from emerging economies and MNEs from the West is that these two groups of companies are in different stages concerning both the internationalisation process and the ownership advantages that they possess. It is here that governments of home countries have a decisive role to play in encouraging, in the home country, the development of the complementary assets needed by their agri-food MNEs: auxiliary industries, services, and sciences and techniques related to agriculture and veterinarian science. The technological strength of the national background is essential for the successful expansion of MNEs, and specifically that of agri-food MNEs, in the early stages of their internationalisation path (Cantwell, 1989; Rama, 1999; Rugman and Nguyen, 2015). Furthermore, the national background can provide these corporations with the ownership advantages needed to embark on stable, long-lasting and non-conflictive agricultural investment abroad. The research work also has implications for host countries. In many of the least developed countries, the expectations placed on attracting foreign investors are deceptive. However, agri-food MNEs that adopt networked forms of organisation seem more likely to contribute towards the development of the host country since this formula implies fewer conflicts with local stakeholders and leaves more benefits in the hands of local partners. Nevertheless, these MNEs usually require skilled local partners and, in this concern, the agricultural education of farmers is essential. Finally, policy makers need to consider that agriculture has unique characteristics: foreign land deals often involve geopolitical issues (Brondeau, 2010), and challenge food security and the living foundation of a substantial part of the population. This is especially true in the least developed countries.

Further research is needed to overcome the major limitations of this study. 
1 One limitation is that the available data is insufficient to enable a detailed analysis of the geography of foreign land deals, FDI included.

2 Evidence remains scarce concerning, specifically, contract farming and 'sowing pools' implemented by agri-food MNEs from emerging economies, and hence further research in this field is needed.

3 On this question, we have confined attention to the possession of ownership advantages as a determinant of the adoption of networked forms of organisation on the part of the agri-food MNE. However, other issues related to the decision to adopt these networked forms have yet to be investigated: the role of law and other specific features of the host country, the social capital of the MNE there and so on. On the limited evidence available, consideration of these aspects seems crucial to understand why the respective levels of embeddedness of agri-food subsidiaries may vary by host countries (Craviotti, 2016).

4 Research on the environmental effects of the networked organisation of agri-food MNEs is also needed.

5 The frequent presence of corruption in land deals, now and in the past, is counterintuitive in the context of IB theory and needs further analysis.

6 Another important question is whether organisational changes and changes in the geographic strategy of the agri-food MNE are interrelated.

7 The control of food chains by companies based in emerging economies is a new phenomenon that deserves more attention than attempted here.

8 Godley (2015) asks whether using historical data is likely to generate further insights concerning MNEs based in nowadays emerging markets. Possible similitude between plantations of early Western agri-food investors and plantations of MNEs from emerging economies need to be investigated; and the relationships of these companies with the local environment in their respective host countries.

Further research needs to be carried out before conclusions can be drawn on agri-food MNEs and, specifically, on agri-food MNEs from emerging economies; however, the present article provides a step in this direction.

\section{Acknowledgements}

The author gratefully acknowledges financial support from project ECO2014-52268-P (Spanish Ministry of Economy and Competitiveness) and wishes to thank the two anonymous referees for their helpful comments and suggestions.

\section{References}

Abreu, M.d.P. (2000) 'British business in Brazil: maturity and demise (1850-1950)', Revista Brasileira de Economia, Vol. 54, No. 4, pp.383-413.

Adamczewski, A., Jamin, J-Y., Burnod, P. and Tonneau, J-P. (2013) 'Terre, eau et capitaux: investissements ou accaparements fonciers à l'Office du Niger?', Cahiers Agricultures, Vol. 22, No. 1, pp.22-32. 
Alfranca, O., Rama, R. and von Tunzelmann, N. (2004) 'Combining different brands of in-house knowledge: technological capabilities in food, biotechnology, chemicals and drugs in agri-food multinationals', Science and Public Policy, Vol. 31, No. 3, pp.227-244.

Arce, A. and Marsden, T.K. (1993) 'The social construction of international food: a new research agenda', Economic Geography, Vol. 69, No. 3, pp.293-311.

Arezki, R., Deininger, K. and Selod, H. (2015) 'What drives the global 'land rush'?', The World Bank Economic Review, Vol. 29, No. 2, pp.207-233.

Aznar-Sánchez, J.A. (2006) La competencia entre la horticultura intensiva de Marruecos y España, CAJAMAR-Thomson Civitas, Cizur Menor, Navarre, Spain.

Bell, D.E. and Scott, C. (2010) Los Grobo: Farming's Future?, Harvard Business School, Cambridge, MA.

Bengoa, J. (1981) 'La expansión del capitalismo en el campo: La fruta y los bosques en Chile', in Arroyo, G. (Ed.): El desarrollo agroindustrial y la economía latinoamericana, Vol. 2, pp.101-121, Secretaría de Agricultura y Recursos Hidraúlicos (Mexico D.F., Mexico).

Borras, S.M., Franco, J.C., Gómez, S., Kay, C. and Spoor, M. (2012) 'Land grabbing in Latin America and the Caribbean', The Journal of Peasant Studies, Vol. 39, Nos. 3-4, pp.845-872.

Brondeau, F. (2010) 'Les investisseurs étrangers à l'assaut des terres agricoles africaines. Réflexions sur le dernier avatar des politiques agricoles post coloniales', EchoGéo, Vol. 14, September/November, pp.1-12.

Bucheli, M. (2008) 'Multinational corporations, totalitarian regimes and economic nationalism: United Fruit Company in Central America, 1899-1975', Business History, Vol. 50, No. 4, pp.433-454.

Bujko, M., Fischer, C., Krieger, T. and Meierrieks, D. (2015) How Institutions Shape Land Deals: The Role of Corruption, Center for Economic Studies \& Ifo Institute, Leibniz.

Burch, D. and Goss, J. (2005) 'Regionalization, globalization, and multinational agribusiness: a comparative perspective from Southeast Asia', in Rama, R. (Ed.): Multinational Agribusinesses, pp.253-282, Haworth Press Inc., NY and London.

Cantwell, J. (1989) Technological Innovation and Multinational Corporations, Basil Blackwell, Oxford and Cambridge.

Cantwell, J. (2000) 'A survey of theories of international production', in Pitelis, C.N. and Sugden, R. (Eds.): The Nature of the Transnational Firm, pp.10-56, Routledge, London and NY.

Cantwell, J., Dunning, J.H. and Lundan, S.M. (2010) 'An evolutionary approach to understanding international business activity: the co-evolution of MNEs and the institutional environment', Journal of International Business Studies, Vol. 41, No. 4, pp.567-586.

Casanova, L. (2010) 'La inversión extranjera directa en América Latina y las multinacionales emergentes latinoamericanas', Real Instituto Elcano Área Cooperación Internacional y Desarrollo, Madrid, September.

CEPAL (1982) Sugar Cane, Alcohol Production and the Interests of Transnational Corporations in Brazil, E/CEPAL/R 324, Santiago de Chile.

Chaponnière, J-R., Gabas, J-J. and Qi, Z. (2011) 'Les investissements agricoles de la Chine', Afrique contemporaine, Vol. 237, No. 1, pp.71-83.

Cotula, L., Vermeulen, S., Mathieu, P. and Toulmin, C. (2011) 'Agricultural investment and international land deals: evidence from a multi-country study in Africa', Food Security, Vol. 3, No. 1, pp.99-113.

Cotula, L., Oya, C., Codjoe, E.A., Eid, A., Kakraba-Ampeh, M., Keeley, J. and Asare, R.O. (2014) 'Testing claims about large land deals in Africa: findings from a multi-country study', Journal of Development Studies, Vol. 50, No. 7, pp.903-925.

Cotula, L., Vermeulen, S., Leonard, R. and Keeley, J. (2009) Land Grab or Development Opportunity? Agricultural Investment and International Land Deals in Africa, International 
Institute for Environment and Development/Food and Agriculture Organisation, International Fund for Agricultural Development, London/Rome.

Craviotti, C. (2016) 'Which territorial embeddedness? Territorial relationships of recently internationalized firms of the soybean chain', The Journal of Peasant Studies, Vol. 43, No. 2, pp.331-347.

Cuervo-Cazurra, A. (2006) 'Who cares about corruption?', Journal of International Business Studies, Vol. 37, No. 6, pp.807-822.

Cuervo-Cazurra, A. and Ramamurti, R. (Eds.) (2015) 'Conclusion: an agenda for EMNC research', in Understanding Multinationals from Emerging Markets, pp.271-299, Cambridge University Press, Cambridge, UK.

Driffield, N., Jones, C. and Crotty, J. (2013) 'International business research and risky investments, an analysis of FDI in conflict zones', International Business Review, Vol. 22, No. 1, pp.140-155.

Dunning, J.H. (1993) The Globalisation of Business, Routledge, London-NY.

Echánove, F. and Steffen, C. (2005) 'Agribusiness and farmers in Mexico: the importance of contractual relations', The Geographical Journal, Vol. 171, No. 2, pp.166-176.

Filippaios, F. and Rama, R. (2008) 'Globalisation or regionalisation? The strategies of the world's largest food and beverages MNEs', European Management Journal, Vol. 26, No. 1, pp.59-72.

Filippaios, F., Pearce, R., Papanastassiou, M. and Rama, R. (2009) 'New forms of organisation and R\&D internationalisation among the world's 100 largest food and beverages multinationals', Research Policy, Vol. 38, No. 6, pp.1032-1043.

Flores, R.G. and Aguilera, R.V. (2007) 'Globalization and location choices: an analysis of US multinational firms in 1980 and 2000', Journal of International Business Studies, Vol. 38, No. 7, pp.1187-1210.

Forsgren, M. (2013) Theories of the Multinational Firm. A Multidimensional Creature in the Global Economy, Edward Elgar, Cheltenham, UK and Northampton, USA.

Frédéricq, A. (1981) 'La producción de leche en Brasil. El caso Nestlé', in Arroyo, G. (Ed.): El desarrollo agroindustrial y la economía latinoamericana, Vol. 2, pp.11-53, Secretaría de Agricultura y Recursos Hidráulicos, Mexico, DF.

Gligor, D.M., Esmark, C.L. and Gölgeci, I. (2015) 'Building international business theory: a grounded theory approach', Journal of International Business Studies, Vol. 47, No. 1, pp.93-111.

Godley, A. (2015) 'What does history add to EMNC research?', in A. Cuervo-Cazurra and R. Ramamurti (Eds.): Understanding Multinationals from Emerging Markets, pp.31-49, Cambridge University Press, Cambridge UK.

Gómez, S. (2014) The Land Market in Latin America and the Caribbean: Concentration and Foreignization, FAO, Santiago de Chile.

Gordillo de Anda, G., de Janvry, A. and Sadoulet, E. (1998) 'Entre el control político y la eficiencia: evolución de los derechos de propiedad agraria en México', Revista de la CEPAL, Santiago de Chile.

Goss, J., Burch, D. and Rickson, R.E. (2000) 'Agri-food restructuring and Third World transnationals: Thailand, the C.P. group and the global shrimp industry', World Development, Vol. 28, No. 3, pp.513-530.

Gwynne, R.N. (2006) 'Governance and the wine commodity chain: upstream and downstream strategies in New Zealand and Chilean wine firms', Asia Pacific Viewpoint, Vol. 47, No. 3, pp.381-395.

Herath, D. and Weersink, A. (2009) 'From plantations to smallholder production: the role of policy in the reorganization of the Sri Lankan tea sector', World Development, Vol. 37, No. 11, pp.1759-1772.

Hopewell, K. (2016) 'The accidental agro-power: constructing comparative advantage in Brazil', New Political Economy, Vol. 21, No. 6, pp.1-19. 
Johanson, J. and Vahlne, J.E. (1977) 'Internationalization process of firm. Model of knowledge development and increasing foreign market commitments', Journal of International Business Studies, Vol. 8, No. 1, pp.23-32.

Katz, J.S. (2016) Adiós al viento de cola: se abre un nuevo ciclo de ajuste structural, CEPAL, Santiago de Chile.

Kay, C. (2015) 'The agrarian question and the neoliberal rural transformation in Latin America', European Review of Latin American and Caribbean Studies, No. 100, pp.73-83.

Luo, Y. and Tung, R.L. (2007) 'International expansion of emerging market enterprises: a springboard perspective', Journal of International Business Studies, Vol. 38, No. 4, pp.481-498.

Magnan, A. (2015) 'The financialization of agri-food in Canada and Australia: corporate farmland and farm ownership in the grains and oilseed sector', Journal of Rural Studies, Vol. 41, pp.1-12.

Mamonova, N. (2015) 'Resistance or adaptation? Ukrainian peasants' responses to large-scale land acquisitions', The Journal of Peasant Studies, Vol. 42, Nos. 3-4, pp.607-634.

McMichael, P. (2012) 'The land grab and corporate food regime restructuring', The Journal of Peasant Studies, Vol. 39, Nos. 3-4, pp.681-701.

Mirza, H., Goodman, Z. and Agostini, A. (2015) 'Responsible agricultural investment: drawing upon best practices in existing initiatives', Transnational Corporations, Vol. 22, No. 2, pp. $25-70$.

Müller, G. (1980) Brasil: las empresas transnacionales en el complejo agroindustrial de ganadería de carne, Instituto Latinoamericano de Estudios Transnacionales, Mexico DF, Mexico.

Nazareth Satyanand, P. (2011) 'India's agriculture and food multinationals: a first look', Transnational Corporations Review, Vol. 3, No. 2, pp.31-49.

Nickerson, C.J., Morehart, M., Kuethe, T., Beckman, J., Ifft, J. and Williams, R. (2012) Trends in US Farmland Values and Ownership, US Department of Agriculture, Economic Research Service, Washington, DC.

Oh, K. (2016) 'Asymmetric effect of institutional distance: MNE subsidiaries' bribery in transition economies', Int. J. Multinational Corporation Strategy, Vol. 1, No. 1, pp.18-43.

Oman, C., Chesnais, F., Pelzman, J. and Rama, R. (1989) New Forms of Investment in Developing Country Industries: Mining, Petrochemicals, Automobiles, Textiles, Food, OECD, Paris.

Pozzobon, D.M. (2008) ‘Explorando soluções internacionais: O caso dos frigoríficos brasileiros’, in EnANPAD (Ed.): XXXI Encontro da ANPAD, pp.1-16, Rio de Janeiro, Brazil.

Rama, R. (1998) 'Growth in food and drink multinationals, 1977-1994: an empirical investigation', Journal of International Food \& Agribusiness Marketing, Vol. 10, No. 1, pp.31-51.

Rama, R. (1999) 'Innovation and profitability of global food firms. Testing for differences in the influence of the home base', Environment and Planning A, Vol. 31, No. 4, pp.735-751.

Rama, R. and Ferguson, D. (2007) 'Emerging districts facing structural reform: the Madrid electronics district and the reshaping of the Spanish telecom monopoly', Environment and Planning A, Vol. 39, No. 9, pp.2207-2231.

Rama, R. and Wilkinson, J. (2012) Asian Agribusiness Investment in Latin America with Case Studies from Brazil, CEPAL, Santiago de Chile.

Ramamurti, R. (2011) 'Impact of the crisis on new FDI players: past, present and future of sovereign wealth funds, private equity and emerging market transnational corporations', Transnational Corporations, Vol. 20, No. 1, pp.39-68.

Rugman, A. and Nguyen, Q.T.K. (2015) 'Modern international business theory and emerging market multinational companies', in Cuervo-Cazurra, A. and Ramamurti, R. (Eds.): Understanding Multinationals from Emerging Markets, pp.53-80, Cambridge University Press, Cambridge, UK. 
Rutherford, T.D. (2000) 'Re-embedding, Japanese investment and the restructuring buyer-supplier relations in the Canadian automotive components industry during the 1990s', Regional Studies, Vol. 34, No. 8, pp.739-751.

Sim, A.B. (2007) 'Emerging Southeast Asian and Taiwanese multinational firms and their internationalization strategies', p.31 in Oxford Business \& Economics Conference, UK.

Slutzky, D. and Alonso, E. (1981) 'La transformación del enclave bananero en Honduras', in Arroyo, G. (Ed.): El desarrollo agroindustrial y la economía latinoamericana, Vol. 1, pp.223-259, Secretaría de Agricultura y Recursos Hidráulicos, Mexico DF.

Stal, E., Sereia, V.J. and Cesso da Silva, R. (2010) 'Estratégias de internacionalização do setor agroindustrial brasileiro de carnes: Exportação ou investimento direto no exterior?', Future Studies Research Journal: Trends and Strategies, Vol. 2, No. 2, pp.132-161.

Stopford, J.M. and Dunning, J.H. (1983) Multinationals. Company Performance and Global Trends, McMillan Publishers, London.

Suárez, B. and Vigorito, R. (1981) 'Capital extranjero y complejos agroalimentarios en América Latina: Historia y estrategia’, Problemas del Desarrollo, Vol. 12, Nos. 47/48, pp.45-60.

UNCTAD (2009) World Investment Report 2009. Transnational Corporations, Agricultural Production and Development, United Nations, Geneva.

Valdés, J.G. (1995) Pinochet's Economists: The Chicago School of Economics in Chile, Cambridge University Press, UK.

Visser, O. and Spoor, M. (2011) 'Land grabbing in post-Soviet Eurasia: the world's largest agricultural land reserves at stake', The Journal of Peasant Studies, Vol. 38, No. 2, pp.299-323.

Wilkinson, J., Reydon, B. and Di Sabbato, A. (2012) 'Concentration and foreign ownership of land in Brazil in the context of global land grabbing', Canadian Journal of Development Studies/Revue canadienne d'études du développement, Vol. 33, No. 4, pp.417-438.

Zoomers, A. (2010) 'Globalisation and the foreignisation of space: seven processes driving the current global land grab’, The Journal of Peasant Studies, Vol. 37, No. 2, pp.429-447.

\section{Notes}

1 The countries of the CIS include Russia and 11 other post-Soviet Eurasian states: Armenia, Azerbaijan, Belarus, Kazakhstan, Kyrgyzstan, Moldova, Tajikistan, Uzbekistan, Turkmenistan, and Ukraine.

2 This literature uses the term 'emerging markets' to mean all countries except the 28 that the International Monetary Fund classified in 2000 as 'developed 'economies (Australia, Austria, Belgium, Canada, Denmark, Finland, France, Germany, Greece, Hong Kong, Iceland, Ireland, Israel, Italy, Japan, Luxembourg, the Netherlands, New Zealand, Norway, Portugal, Singapore, South Korea, Spain, Sweden, Switzerland, Taiwan, the UK, and the USA). Although we admit that not all are 'emerging economies' stricto sensu, the present article follows the terminology used by this literature for the sake of consistency. Obviously, this broad definition encompasses very different countries.

3 The Convention was signed by OECD countries and by several developing countries, such as Argentina, Brazil, and Chile (Cuervo-Cazurra, 2006).

4 Banco do Brasil. November 2015. Retrieved from http://www4.bcb.gov.br/rex/cbe/port/ ResultadoCBE2013.asp?idpai=CBE.

5 The Economist, 21st to 27th January, 2012; report on 'State Capitalism'.

6 Nevertheless, during the plantation era, political intervention of Western governments was common (see, for instance, Bucheli, 2008). 
7 Other economists had declined invitations to collaborate with the military regime due to their concern with human-rights issues. In contrast, the so-called 'Chicago boys' were not concerned about such issues or about social consequences of neoliberal reform, since they believed that economics was a 'neutral' science (Valdés, 1995).

8 FAO defines land grabs in terms of three aspects:

1 large-scale land acquisitions

2 involvement of foreign governments in the land deals

3 negative impact of such foreign investments on the food security of the host country.

9 Additionally, certain agri-food MNEs from South America and Asia are involved in contract farming at home or abroad (Bengoa, 1981; Burch and Goss, 2005). The scarce evidence suggests that these companies display a common trait with Western MNEs that also engage in contact farming: they possess $\mathrm{O}$ advantages, such as well-known brand names and distribution networks, at least at the regional level.

10 I thank Dr. Clara Craviotti for elucidating this question.

11 Los Grobo. June 2016. Retrieved from http://www.losgrobo.com.ar/sala-de-prensa/novedades. html? start $=45$.

12 Wesz Jr., V. (2014) O mercado da soja e as relacões de troca entre produtores rurais $e$ empresas no sudeste do Mato Grosso (Brasil), $\mathrm{PhD}$ thesis, Universidade Federal do Rio de Janeiro, Rio de Janeiro (cited by Craviotti, 2016). 